\title{
Reconstitution of Iron Cores in Horse Spleen and Yeast-derived Recombinant Human H- and L-chain Ferritins
}

\author{
Sung-Won Kim, Min-Young Jo, Yasuhiro Yokota, ${ }^{\ddagger}$ Yun-Jo Chung, Chung-Ung Park, and Kyung-Suk Kim* \\ Facultr of Biological Sciences, Institute for Molecular Biologv and Genetics, \\ Chonbuk Kational Chiversit, Chonju 561-756, Korea \\ -Basic Science Research Institute. Chonbuk Vational Universin, Chonju $561-756$. Korea \\ ${ }^{\ddagger}$ Research Institute of Natural Science, Okavama University of Science. Okavama 700-0005, Japan \\ Received December 1, 2003
}

\begin{abstract}
Recombinant human ferritin homopolymers ( $\mathrm{rHF}$ and $\mathrm{rLF}$ ) were successfilly produced in the Saccharomyces cerevisiae Y2805, which was transformed with human ferritin $\mathrm{H}$ or L-chain genes. respectively. In order to characterize the molecular properties of the recombinant ferritins in relation to mineralization. the proteins were isolated and apoferritins were prepared. The apoferritins were reconstituted with $2000 \mathrm{Fe}$ atoms per protein molecule under various experimental conditions (the concentration of the protein. the buffer concentration of the MOPS buffer. the total volume of the reaction and the reconstitution method). The structure and composition of the iron cores formed in the ferritins were examined using transmission electron microscopy. The recombinant ferritins behaved in a similar manner to other mammalian ferritins in accumulating iron in the core. Proteins of $\mathrm{rHF}$ and $\mathrm{rLF}$ showed varying reconstitution yields of $37-72 \%$ depending on the reaction conditions. In general, the rHF showed higher reconstitution yield than the $\mathrm{rLF}$ at the protein concentrations and the reaction volumes we examined. Iron cores with a similar mean particle size were obtained in the rHF, $\mathrm{rLF}$ and horse spleen ferritin reconstituted at a protein concentration of $1.0 \mathrm{mg} / \mathrm{mL}$. Electron diffraction of all the three ferritins showed 2-3 diffuse lines. with d-spacings corresponding to those of the mineral ferrihydrite with a limited cry'stallinity.
\end{abstract}

Key Words : Yeast-derived recombinant human ferritin homopolymers. Iron core, Reconstitution. Electron microscopy

\section{Introduction}

Biomineralization is a process where metal ions are deposited as solid phases in a biological enviromment i.e. living organisms, by absorption, adsorption or by some other mechanism. One of the prominent features on the biomineralization process is that the nucleation and growth of the biomineral phase is carefully controlled by organic matrix biopolymers. ${ }^{l}$ An example of a bionineralization within specific compartments or microenviromments is the iron storage protein. ferritin. Protein cages with nanometersized carities provide the reaction environments that control the biomineral size, the specific shape, the chenical composition. the crystal morphology and the crystal structure. Nanoparticles are arising as an important component of advanced materials with its novel optic electrical. magnetic and catalytic characteristics due to their small size..$^{2.3}$

Ferritin. which is a ubiquitous iron protein among living species. is a spherical protein with a diameter of $12 \mathrm{~lm}$ and is composed of 24 polypeptide subunits. It contains a $8 \mathrm{~nm}$ diameter core, in which a large amount of $\mathrm{Fe}$ atoms (up to 4500 atoms) is stored as the mineral ferrilydrite $\left(5 \mathrm{Fe}_{2} \mathrm{O}_{3}\right.$. $9 \mathrm{H}_{2} \mathrm{O}$ ). In most vertebrates. ferritins that are present in various tissues consist of two main subunits, heavy (known

Corresponding Author. Tel: +82-63-270-3341: Fax: +82-63270-3345; e-mail: sukkintànoak chonbuk ac.kr as heart type, or $\mathrm{H}$ ) and light (known as liver type, or $\mathrm{L}$ ). The molecular weights of the subunits are $21 \mathrm{kDa}$ and $19 \mathrm{kDa}$. respectively. ${ }^{4.5}$ Although tissue isoferritins have functional differences that may be related to variations in the subunit composition, the functional differences of the two subunits in wivo are not clearly defined. In relation to the in vitro function of the subunits. iron cores of Escherichia coliderived recombinant human $\mathrm{H}$ - and $\mathrm{L}$-chain ferritins $(\mathrm{H}$ - and L-ferritins, respectively) and its variants were previously examined by transmission electron microscopy (TEM). Compared to the $\mathrm{H}$-ferritin. the L-ferritin showed significantly reduced iron uptake rate and cores of increased diameter and regularity upon reconstitution. ${ }^{6}$ Electron microscopic studies of ferritin reconstituted with $\mathrm{Mn}, \mathrm{Al}$ and $\mathrm{UO}_{2}$ were also performed. ${ }^{7-1(1)}$ Such studies provide convenient ways of synthesizing nano-structured minerals with different crystal characteristics in the constrained cavity of the protein. A different approach was also proposed. in which the fabrication of a two-dimensional array of nano-particles was made using ferritin molecules. ${ }^{\text {ll }}$ However. reconstitution studies with recombinant ferritin homopolymers produced in eukaryotic organisms have not been made.

In this study, recombinant human $\mathrm{H}$ - and L-chain ferritin homopolymers (rHF and rLF), which are produced in recombinant Saccharomyces cerevisiae Y2805, were for the first time subjected to the formation of biominerals, to the best of our knowledge. A variety of reaction factors such as 
the protein concentration, the buffer concentration and the total volume were examined in the reconstitution experiments. Upon reconstitution, the morphology and chemical composition of the nanometer-sized biominerals formed in the recombinant ferritins were analyzed by TГM and electron diffraction.

\section{Materials and Methods}

Yeast Strains and Expression of Ferritin from Yeast. $S$. cenevisiae 2805 (MAla pept::HIS3 prb1-d canl GAL2 his3 ura3-52) was used as a host strain for the heterologous expression of the human ferritin $\mathrm{H}$-chain $(h / H)$ and $\mathrm{I}$,-chain ( $h f L$ ) genes. $S$. cerevisiae cells expressing $h f H$ and $h f L$ were denoted as strains $\mathrm{YGH}_{2}$ and $\mathrm{YGl}, 1$, respectively. ${ }^{12}$ The horse spleen ferritin was purchased from Sigma. Precultures of the $S$. cerevisiae cells were cultured on a YFP ( $1 \%$ yeast extract) medium supplemented with $2 \%$ galactose at $30{ }^{\circ} \mathrm{C}$ for 3 datys with continuous agitation $(200 \mathrm{rpm})$. The cells were then harvested by centrifugation at $5,000 \mathrm{~g}$ for $10 \mathrm{~min}$ $\left(4{ }^{\circ} \mathrm{C}\right)$ and washed twice with distilled water and once with $20 \mathrm{mM}$ Tris/ $\mathrm{HCl}$ buffer ( $\mathrm{pH} 7.4$ ). The cells were disrupted in a bead beater (Biospec Products Inc. Okla. USA) for 3 min and the lysates were centrifuged at $10,000 \mathrm{~g}$ and $4{ }^{\circ} \mathrm{C}$ for 10 min.

Purification of the Recombinant Ferritins. The purification of the recombinant $\mathrm{H}$ - and $\mathrm{I}$-ferritins from the recombinant yeasts was achieved using a slight modification of the methods reported by Santambrogio et $a l^{13}$ The rHF was purified by heat denaturation at $70-75^{\circ} \mathrm{C}$ for $10 \mathrm{~min}$ and $80 \%$ ammonium sulfate precipitation followed by gel filtration on Sephacryl S-300. In the case of rl.F, a combination of Sephacryl S-200 and DГАГ-Sephacel ion exchange chromatography was used to purify the protein from the recombinant $S$. cervisiac. The purity of the isolated proteins was examined by polyacrylamide gel electrophoresis (PAGF).

Iron Uptake by Recombinant Ferritin. The apoferritins from the purified ferritins were prepared by chemical reduction as described previously. ${ }^{14}$ 'The rate of iron uptake by the ferritin was measured using the method reported by Chang $e t a l^{15}$ Protein concentration was determined by the modified Lowry method. ${ }^{16}$ A reaction was initiated by addition of $\mathrm{Fe}(\mathrm{ll})$ to the apoferritin solution in the $\mathrm{Fe}$ /protein ratio of 400 . A freshly prepared $2 \mathrm{mM}$ ferrous ammonium sulfate was added to apoferritin $(0.5 \mathrm{mg} / \mathrm{mL})$ in $20 \mathrm{mM}$ imidazole buffer ( $\mathrm{pH} 7.0$ ). The iron uptake was observed by measuring the change in the absorbance at $310 \mathrm{~nm}$ until the absorbance reached a maximum value (Hitachi U-3300 spectrometer). Additional oxidants were excluded and the $\mathrm{Fe}^{2+}$ was oxidized by dissolved oxygen.

Reconstitution of Ferritin. 'The apoferritin was reconstituted by the addition of a freshly prepared $20 \mathrm{mM}$ ferrous ammonium sulfate in MOPS (3-[N-morpholino] propane

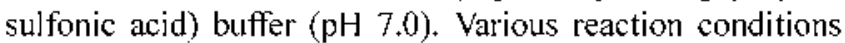
including the protein concentration, the buffer concentration of the buffer and the reaction volume was examined. Two different reconstitution methods were performed as previously described by Wade ot $a{ }^{6}$ One method was performed by the addition of $\mathrm{Fe}^{2-}$ in four steps at RT with $1 \mathrm{~h}$ intervals to give a calculated loading of $2000 \mathrm{Fe}$ atoms per protein molecule. The other method was carried out by the stepwise addition of $\mathrm{Fe}^{2-}$ over 20 times at RT with 15 min intervals to give 2000 $\mathrm{Fe}$ atoms per protein molecule. The reaction product was stored at 4 "C for $18 \mathrm{~h}$, followed by extensive dialysis aisainst $\mathrm{H}_{2} \mathrm{O}$. The reconstituted ferritin was filtered using a $0.45 \mu \mathrm{m}$ filter (Millipore) in order to remove the aggregates that might have occurred during reconstitution. Upon reconstitution, the concentration of iron in the ferritin core was analyzed by a modified L cowry method for proteins ${ }^{10}$ and atomic absorption spectrometry (AAS; SpectiAA-400, Varian) for the iron. Unstained samples of the native and reconstituted human ferritins were prepared for electron microscopy by air-drying small drops of the solution onto Formvarcoated copper grids. Samples were negatively stained using $2 \%$ phosphotungstic acid to examine the conformation of the protein shells. The electron microscopic images were obtained on a ГГОL JГ:M 2010 operating at $160 \mathrm{keV}$. Dense areas of the ferritin cores were selected for the electron diffraction patterns. The length of the calibrated camera was $100 \mathrm{~cm}$. The particle sizes were determined by measuring 50 iron cores from enlarged photomicrographs.

\section{Results and Discussion}

Reconstitution of the horse spleen and the recombinant human ferritins with $\mathrm{Fe}^{2+}$ was traced by an increase in absorbance at $310 \mathrm{~nm}$. The progress curve of $\mathrm{F} \mathrm{e}^{\text {i- }}$ formation at an iron concentration of $400 \mathrm{Fe}$ atoms per protein molecule among the proteins was compared, as shown in Figure 1. The progress curve of $\mathrm{Fe}^{2+}$ oxidation was hyperbolic for $r \mathrm{HF}$, whereas it was sigmoidal for $\mathrm{rl}$. $\mathrm{F}$ and the horse spleen ferritin (HSF). The reaction of $\mathrm{rHF}$ showed the fastest increase in the initial rate and terminated in approximately 5 min, being comparable to that of $E$, coli-derived $\mathrm{rHF} .^{17}$

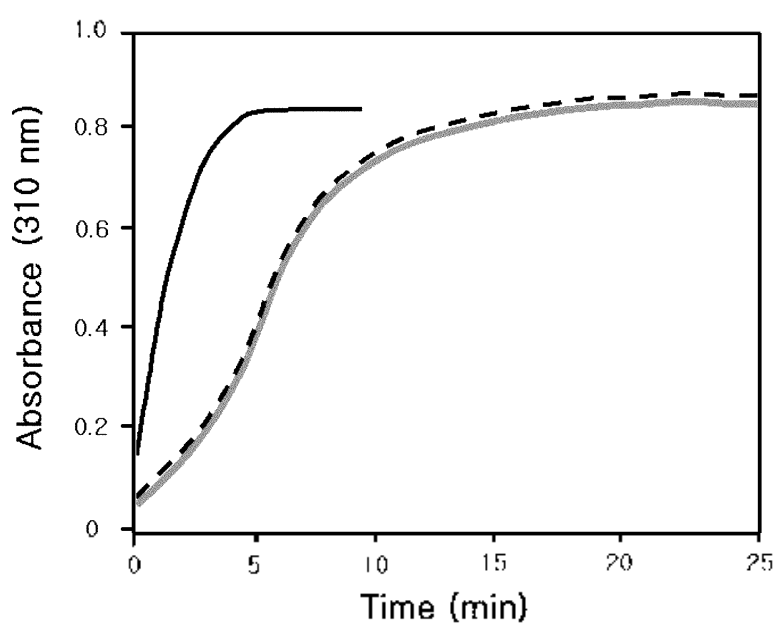

Figure 1. Iren uptake measurement for the human II- and L-chain ferritins. and horse splecn ferritin. The protein concentrations are $0.5 \mathrm{mg} / \mathrm{mL}$. and the $\mathrm{Fe}^{2-}$ protein was 400 . rHF. solid kinetic curve: I. $\%$ dashed kinetic curve: HSF, gray solid kinetic curve. 
Table 1. Reconstitution yield of HSF (horse spleen ferritin) depending on ionic strengths ( 10 and $20 \mathrm{mM}$ MOPS, $\mathrm{pH} 7.0$ ), reaction volumes $(1.5$ and $3.0 \mathrm{mg} / \mathrm{mL}$ ) and protein concentrations $(0.5$ and $1.0 \mathrm{mg} / \mathrm{mL})$. The proteins were reconstituted with $2000 \mathrm{Fe}$ atoms per molecule of protein

\begin{tabular}{cccccc}
\hline $\begin{array}{c}\text { Theoretical } \\
\text { amount }^{\sigma}\end{array}$ & $\begin{array}{c}\text { MOPS } \\
\text { buffer }(\mathrm{mM})\end{array}$ & $\begin{array}{c}\text { Protein conc. } \\
(\mathrm{mng} / \mathrm{mL})\end{array}$ & $\begin{array}{c}\text { Reaction } \\
\text { volume }\end{array}$ & $\begin{array}{c}\text { Analytical } \\
\text { amount.b }\end{array}$ & $\begin{array}{c}\text { Yield } \\
(\%)\end{array}$ \\
\hline 2000 & 10 & 0.5 & 1.5 & $1391 \pm 57$ & 69.6 \\
& 10 & 0.5 & 3.0 & $1449 \pm 19$ & 72.5 \\
& 10 & 1.0 & 1.5 & $570 \pm 12$ & 28.5 \\
& 10 & 1.0 & 3.0 & $1221 \pm 16$ & 31.1 \\
\hline 2000 & 20 & 0.5 & 1.5 & $1376 \pm 28$ & 61.0 \\
& 20 & 0.5 & 3.0 & $1016 \pm 66$ & 68.8 \\
& 20 & 1.0 & 1.5 & $1201 \pm 2$ & 50.8 \\
\hline
\end{tabular}

"Values are Fe atoms per protein molecule present in ferritin after reconstitution. "Values are obtained from three replicates.

However. the oxidation of $\mathrm{Fe}^{\hat{3}+}$ in rLF terminated in approximately $20 \mathrm{~min}$, appearing faster than the $E$. coli-derived ILF. The result is somewhat coniparable to a previous report in that the $E$. coli-derived $\mathrm{rHF}$ exhibited a faster uptake rate than $E$. coli-derived $\mathrm{rLF}^{17,18}$ The iron uptake of the HSF was similar to that of the rLF under the experimental condition. The result demonstrates that the $\mathrm{H}$ - and L-ferritins produced in yeast are as active as the native protein in vitro.

The iron concentration and reconstitution yield after reconstituting the HSF with $\mathrm{Fe}^{2-}$ ions are shown in Table 1. The iron contents of the HSF $(0.5 \mathrm{mg} / \mathrm{mL})$. which were reconstituted with $2000 \mathrm{Fe}$ atoms per protein molecule in 10 $\mathrm{mM}$ MOPS ( $\mathrm{pH} 7.0$ ) using either reconstitution method. were analyzed as $139 \mathrm{l} \pm 57$ (reaction volume: $1.5 \mathrm{~mL}$ ) or $1+49 \pm 19(3.0 \mathrm{~mL})$. At a higher protein concentration $(1.0$ $\mathrm{mg} / \mathrm{mL})$, the iron contents decreased to either $570 \pm 12(1.5$ $\mathrm{mL})$ or $623 \pm 11(3.0 \mathrm{~mL})$ in the same buffer concentration of buffer solution. A similar tendency was observed: when 1) the reconstitution experiment was performed in $20 \mathrm{mM}$

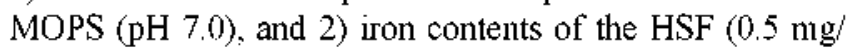
$\mathrm{mL}$ ) were analyzed as either $122 \mathrm{l} \pm 16(1.5 \mathrm{~mL})$ or $1376 \pm$ $28(3.0 \mathrm{~mL})$. At a higher protein concentration $(1.0 \mathrm{~m} \mathrm{~g} / \mathrm{mL})$. iron concentration decreased to either $1016 \pm 66(1.5 \mathrm{~mL})$ or $1201 \pm 2(3.0 \mathrm{~mL})$ but the decrease was less significant than that observed at the lower protein concentration. When the buffer concentration of the reaction was doubled at high protein concentrations $(1.0 \mathrm{mg} / \mathrm{mL})$, the reconstitution yield increased nearly as much as the increase in the buffer concentration. No differences in the reconstitution yield were observed for the different reconstitution methods (data not shown). The reaction volume of the HSF affects the reconstitution yield (Table 1). The reconstitution yield slightly increased as the reaction volume was increased. The maximum yield $(72.5 \%)$ was obtained when the reaction was performed at $0.5 \mathrm{mg} / \mathrm{mL}$ HSF $(3.0 \mathrm{~mL})$ in $10 \mathrm{mM}$ MOPS ( $\mathrm{pH} 7.0)$. On the other hand, the minimum yield (28.5\%) was obtained at $1.0 \mathrm{mg} / \mathrm{mL}$ HSF $(1.5 \mathrm{~mL})$ in $10 \mathrm{mM}$ MOPS $(\mathrm{pH} 7.0)$. The reconstitution yield was calculated as the percentage of the iron $(\mu \mathrm{g})$ incorporated by the proteins per total iron $(\mu \mathrm{g})$ reacted.

Under electron microscopy, the recombinant ferritins were observed as globular proteins, with sizes comparable to their corresponding tissue ferritins. The reconstituted cores of the rHF and rLF are well identified. which suggests that the recombinant ferritins are well assembled to form a core in a manner analogous to the native tissue ferritins and iron mineralization occurs is in a similar way as in the $E$. coliderived ferritins. ${ }^{6}$ The rHF and rLF were compared after being reconstituted with $2000 \mathrm{Fe}$ atoms per protein molecule in $20 \mathrm{mM}$ MOPS (pH 7.0). The effect of the protein concentration was examined and the protein concentration of 0.5 $\mathrm{mg} / \mathrm{mL}$ resulted ligher reconstitution yields than $1.0 \mathrm{mg} / \mathrm{mL}$ (Table 2). Such a tendency is similar to that observed in the HSF. The result indicates that proteins are competitive to the neighboring molecules in accumulating iron atoms as the protein concentration increases in the system. and the

Table 2. Reconstitution yield of ferritin depending on protein concentrations $(0.5$ and $1.0 \mathrm{mg} / \mathrm{mL})$. The rHF and rLF were reconstituted in two volumes $(0.5$ and $3.0 \mathrm{~mL}$ ) of $20 \mathrm{mM}$ MOPS ( $\mathrm{pH} 7.0$ ) with $2000 \mathrm{Fe}$ atoms per molecule of protein

\begin{tabular}{|c|c|c|c|c|c|}
\hline $\begin{array}{l}\text { Protein } \\
\text { type }\end{array}$ & $\begin{array}{l}\text { Theoretical } \\
\text { amount }\end{array}$ & $\begin{array}{c}\text { Protein conc. } \\
(\mathrm{mg} / \mathrm{mL})\end{array}$ & $\begin{array}{c}\text { Reaction } \\
\text { volume }\end{array}$ & $\begin{array}{l}\text { Analytical } \\
\text { Amount }{ }^{2 . b}\end{array}$ & $\begin{array}{l}\text { Yield } \\
(\%)\end{array}$ \\
\hline \multirow[t]{4}{*}{$\mathrm{rHF}$} & 2000 & 0.5 & 1.5 & $1272 \pm 15$ & 63.6 \\
\hline & & 0.5 & 3.0 & $1448 \pm 15$ & 72.4 \\
\hline & & 1.0 & 1.5 & $1000 \pm 6$ & 50.0 \\
\hline & & 1.0 & 3.0 & $1288 \pm 18$ & 64.4 \\
\hline \multirow[t]{4}{*}{ rLF } & 2000 & 0.5 & 1.5 & $1082 \pm 45$ & 54.1 \\
\hline & & 0.5 & 3.0 & $1185 \pm 47$ & 59.3 \\
\hline & & 1.0 & 1.5 & $738 \pm 32$ & 36.9 \\
\hline & & 1.0 & 3.0 & $1089 \pm 17$ & 54.5 \\
\hline
\end{tabular}

\footnotetext{
"Values are Fe atoms per protein molecule present in ferritin after reconstitution. "Values are obtained from three replicates.
} 
reconstitution yield is then decreased. Cnder the experimental conditions. the rf $[F$ showed the hightst level of reconstitution whereas the rLF showed the lowest. The yield is in the order of $\mathrm{rHF}>\mathrm{HSF}>\mathrm{rLF}$. which suggests that the reconstitution is related to the content of the l l-subunit ie. the Perroxidase activity in this protein. This agrees with the result of the iron uplake kinelics in vitro (Figure 1). However. where the iron uptake rale for the IISF (15\% II subunit. $85 \%$ L subunit) was comparable to the rLF. the IISF showed a higher reconstitution yield than rLF. This result suggests that as the mincralization in IISF progresses. the iron uplake reaction begins slowly in the beginning and the rate increases as the mineral core fills up. Therefore. it indicales that autocalalysis of core formation had more influenec on the higher reconstitution yield in ISSF. It has been suggested that ferritins composed of more than $18 \mathrm{~L}$ subunits among 24 subunits incorporate more iron into the soluble 24 -mers than the hemopolymers. ${ }^{19}$ The reconstitution yield increases as the reaction volume increases (Table 2). When the reaction volume increased by 2 times. the yield increased by $12 \%$ on average in the proteins of the rl JF. rI, F and HSF. The reason for the increase is unclear. but we suspect that the kinetic rate of the Fe ions and the amount of the dissolved $\mathrm{O}_{2}$ may have inllueneed on the reconslitution.

Fiectron photomicrographs of the reconslituted ferritins in the unstained images are shown in Figure 2. The images of the discrete electron dense cores indicate that the reconstitutions are well performed as reported with the $E$. coliderived ferritins. ${ }^{6}$ "The reconstituted cores of the rl II" and the rL $F$ appear to be generally spherical in shape with the populations being angular (Figure 2a-d). In particular. a large variation in the core size of the rI, F was observed. The reconstituted I ISF also showed a large population of angular cores with different size variations (Figure $2 \mathrm{e}$ and $\mathrm{f}$ ). The electron dense cores were encapsulated within the protein shells. as shown in the negalively stained images of the lerritins, demonstrating that the minerals are well formed in the cores and some emply cores are lelt over alter mineraljzation (Figure $2 \mathrm{~g}$ and $\mathrm{h}$ ).

Comparisons of the recombinant ferritins reconstituted at the different protein concentrations were made in relation to the morphology and chemical composition of the core mineral. The particle size distribution of the recombinant ferritins and the HSF that was reconstituted under the same experimental condition is compared in Figure 3. and the size data is shown in Table 3 . The core size of the rl FF $(0.5 \mathrm{mg} /$ $\mathrm{mL}$ ). which was reconstituted with a yield of $72.4 \%$. ranged from 5.89 to $9.70 \mathrm{~nm}$ with a mean value of $7.67 \mathrm{~mm}$. and shows a lower size variation. In contrast. the rHF of $1.0 \mathrm{mg} /$ $\mathrm{mL}$ that were reconstituted with a yield of $64.4 \%$ ranged from 4.33 to $8.03 \mathrm{~nm}$ with a mean value of $6.52 \mathrm{~nm}$ (Table 3 . Figure $3 \mathrm{a}$ and b). In the ease of the rl.F $(0.5 \mathrm{mg} / \mathrm{mI}$ ). the protein reconstituted with a yield of $59.3 \%$ shows a core with a mean size of $6.22 \mathrm{~nm}$. The particle size distribution of the rLF was observed over a wide range. as shown on the micrograph. This value increased to $6.92 \mathrm{~nm}$ when the rLF $(1.0 \mathrm{mg} / \mathrm{mL})$ was reconstituted with a yield of $54.5 \%$. A
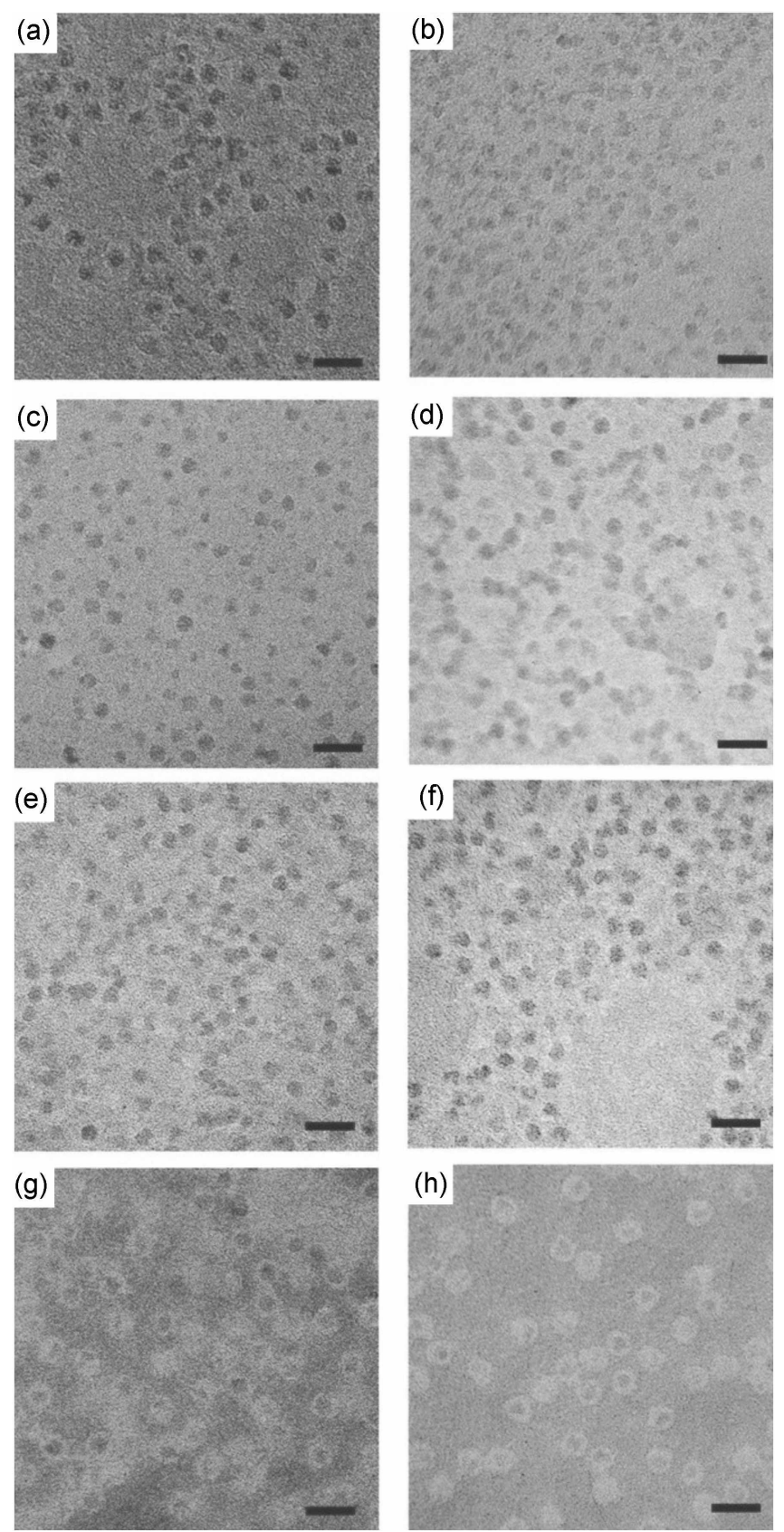

Figure 2. Transmission electron micrographs of the iron cores of the reconstituted rHF, rLF and HSF. The scale bar presents $20 \mathrm{~nm}$ in all micrographs. (a) and (b) $\mathrm{rHF}$ in two protein concentrations $(0.5$ and $1.0 \mathrm{mg} / \mathrm{ml}$.) $(\mathrm{c})$ and (d) $\mathrm{rl} . \mathrm{F}$ in two protein concentrations $(0.5$ and $1.0 \mathrm{mg} / \mathrm{ml}$.) (e) and (f) $\mathrm{HSSl}$ in two protein concentrations $(0.5$ and $1.0 \mathrm{mg} / \mathrm{mL}$ ): (g) $\mathrm{rHF}$ negatively stained in a protein concentration of $0.5 \mathrm{mg} / \mathrm{ml}$ : (h) rl.F negatively stained in a protein concentration of $0.5 \mathrm{mg} / \mathrm{ml}$

narrower particle size distribution was obtained in the $\mathrm{rLF}$ at this condition (Table 3. Figure $3 \mathrm{c}$ and d). but the reason for this is unclear. Previously. I cevi et $a I^{18}$ reported a functional difference between $\mathrm{l}$ - and L-ferritins both produced in $E$. coll and reported that the L-chain ferritin has a higher capacity to induee iron-core nucleation than the H-chain ferritin. In the HSF. the increase in the reconstitution yield from $60.0 \%(1.0 \mathrm{mg} / \mathrm{mL})$ to $68.8 \%(0.5 \mathrm{mg} / \mathrm{mL})$ does not 


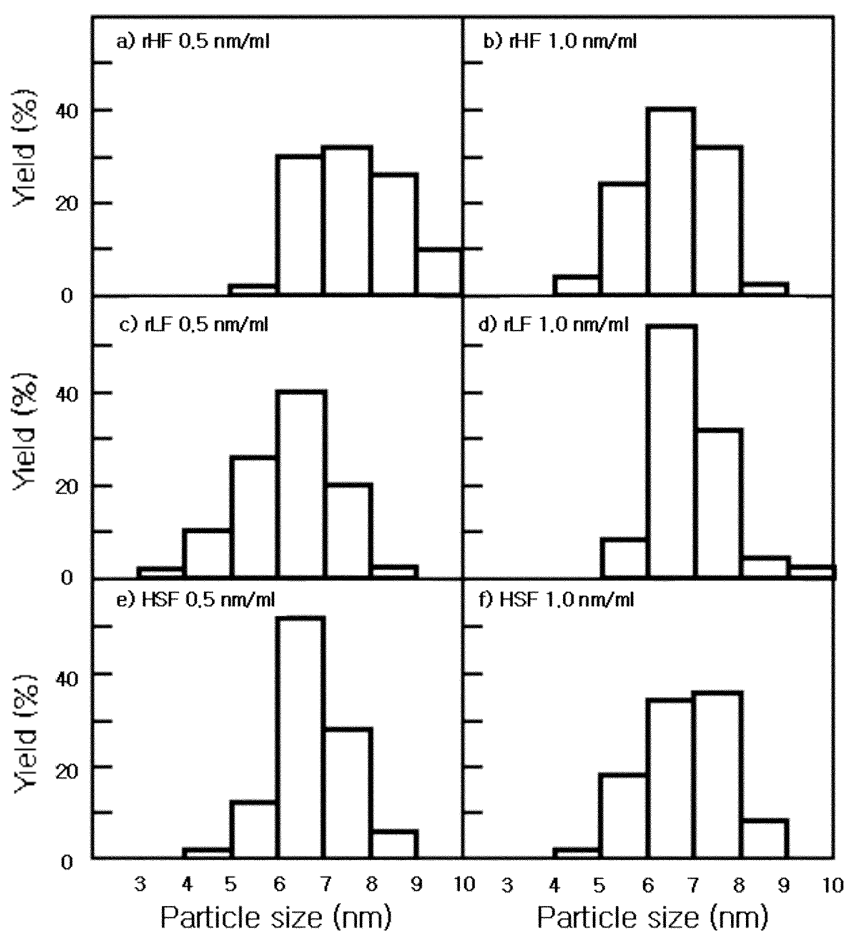

Figure 3. Parlicle size dislributions of the rl IF, rl, and IISI:

significantly affect the core size. The core size of the HSF $(0.5 \mathrm{mg} / \mathrm{ml}$ ) ranged from 4.92 to $8.76 \mathrm{~nm}$ with a mean value of $6.74 \mathrm{~nm}$ whereas the HSF of $1.0 \mathrm{mg} / \mathrm{ml}$, range from 4.16 to $8.48 \mathrm{~nm}$ with a mean value of $6.67 \mathrm{~nm}$ (Table 3 . Figure $3 \mathrm{e}$ and f). Comparable results were obtained previously where the core size of the HSF (reconstitution yield of $55.0 \%$ ) 6.17 $n m$ on average. ${ }^{1.1}$ Interestingly, all the ferritins with a protein concentration of $1.0 \mathrm{mg} / \mathrm{mL}$. showed somewhat similar core size despite of the variation in the reconstitution yields. However, it was found that there were some differences in the core size of the ferritins of $0.5 \mathrm{mg} / \mathrm{ml}$.. The core distribution of the HSF $(0.5 \mathrm{mg} / \mathrm{ml}$ ) revealed a low population of small cores, which also indicates that the reaction is autocatalytic. A comparison of the yeast-derived human $\mathrm{rHF}$ with the E. coli-derived human $\mathrm{rHF}$ showed such a large difference in core size that our yeast-derived r $\mathrm{HF}$ was far larger than the $E$. coll-derived $\mathrm{rHF}^{-6}$ Obviously, the core sizes

Table 3. Particle size data of recombinant human $\mathrm{H}$ - and L-chain lerritins. and horse spleen ferritin

\begin{tabular}{cccc}
\hline $\begin{array}{c}\text { Protein } \\
\text { type }\end{array}$ & $\begin{array}{c}\text { Protein Conc. } \\
(\mathrm{mg} / \mathrm{ml})\end{array}$ & $\begin{array}{c}\text { Particle } \\
\text { Metan }(\mathrm{nm})\end{array}$ & $\begin{array}{c}\text { Particle } \\
\text { Range }(\mathrm{nm})\end{array}$ \\
\hline rHF & 0.5 & 7.67 & $5.89-9.70$ \\
& 1.0 & 6.52 & $4.33-8.03$ \\
$\mathrm{rLF}$ & 0.5 & 6.22 & $3.91-8.76$ \\
& 1.0 & 6.92 & $5.71-9.70$ \\
$\mathrm{HSF}$ & 0.5 & 6.74 & $4.92-8.76$ \\
& 1.0 & 6.67 & $4.16-8.48$ \\
$\mathrm{rHF}(\mathrm{s})-$ & 0.5 & 11.60 & $9.19-13.59$ \\
$\mathrm{rLF}(\mathrm{s})+$ & 1.0 & 11.30 & $8.86-12.81$ \\
\hline
\end{tabular}

$\because$ : (s) means stained protein should be compared carefully since there will be some differences depending on the reaction conditions. There is no report so far on the core size and particle size distribution of ferritin that was reconstituted at the different experimental conditions. It was reported that the core size varies as a result of the reconstitution methods. ${ }^{6}$ These results clearly demonstrate that the reconstitution yield is higher with a low protein concentration and a large reaction volume of apoferritin, and the core size of the reconstituted ferritins can vary upon reconstitution.

The differences in the electron diffraction patterns of the proteins were not apparent, because the diffraction lines were diffused and consisted of only three lines at $d$ spacings, $0.25 \mathrm{~nm}, 0.21 \mathrm{~nm}$ and $0.12 \mathrm{~nm}$. The minerals were assigned as being a ferrihydrite with them being either amorphous or with a poor crystallinity.

In conclusion, the recombinant ferritin homopolymers that are produced in eukaryotic organisms were first characterized in terms of the molecular properties of the core mineralization. The $\mathrm{rHF}$ and $\mathrm{rl} . \mathrm{F}$ behaved in a similar manner to the $E$. col $i$ derived recombinant ferritins. The effect of the various reaction factors including the protein concentration, the buffer concentration of the MOPS buffer and the total reaction volume on the formation of core minerals was examined. The plysicochemical properties of the core minerals were closely related to the proteins and the reaction factors. Therefore, this study demonstrates the potential of synthesizing nano-structured minerals with different crystal characteristics in the core of recombinant ferritin homopolymers obtained from yeast. Further analyses on the magnetic properties of the nano-structured minerals will be of great interest for wide applications.

Acknowlegements. We thank Dr. S. L evi for providing human ferritin $\mathrm{H}$ - and $\mathrm{I}$-chain cDNAs. This study was supported by a grant from Korea Research Foundation (C00063, 2002).

\section{References}

1. Mann, S. Nattwe 1988 332.119.

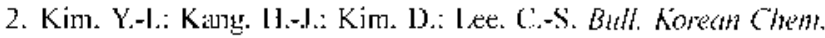
Soc. 2003. 24.593.

3. Jeong. Y. l.: Ryu. J. G.: Kim. Y. H.: Kim. S. H. Bull Konean (he'm. Soc. 2002. 23. 872 .

4. Harrison. P. M.: Arosio. P. Biochim. Biophns, Acta 1996, /275, 161 .

5. Chasteen. M. I).: I laurison. P. M. J. Sitwe. Biol. 1999. /26. 182.

6. Wade V. I.: Levi. S.: Arosio. P.: Trelfiry. A.: Harrison. I'. M.: Mann. S. J. Mot Biol. 1991. 22l. 1443.

7. Meldrum. F. C.: Douglas. T.: Levi. S.: Arosio. P.: Mann. S. J. horg. Biochen. 1995 . 58.59.

8. Mun, Il.-R.: Kim, K.-S.: I ce, J.-II. Aot Soc: Electon Wicroseropy 1999. 29. 323

9. Mann. S.: Meldrum. F. C. Adu Mater 1991. 3. 316.

10. Meldrum. F. C.: Wade. V. J.: Vimmo. D. L.: Heywood. B. R.: Mann. S. Nature 1991. 349. 684.

11. Yamashitas 1. Thin Solid Hilms 2001. 393. 12

12. Sto, II.-Y.: Chung. Y.-1: Kim. S.-I.: Park. C.-U.: Kim, K.-S. Appl. Microbiol Biotech 2003. 63. 57. 
13. Santambrogio. P.: Levi. S.: Cozzi. A.: Rovida. E: Albertini. A.: Arosio. P. J. Biol. Chem 1993. 268. 12744

14. Kim, K.-S.: Mun, H.-R.: Lee. T.-H. Inorg Chim data 2000. 298. 107.

15. Chang. S.-R.: Kim, Y.T.: Kim, K.-S. J. Biochem. Hol. 1995. 28. 238

16. Hess. H. H.: Lees. M. B.: Derry. J. E. Anal. Biochem. 1978. 85. 295 .
17. Levi. S.: Salteld. J.: Franceschinelli. F.: Cozzi. A.: Dorner. M.: Arosio. P. Biochemishy 1989. 28.5179.

18. Levi, S.; Yewdall. J.: Harrison, P. M.: Santambrogio P: Cozzi, A.; Rovida, E.: Albertini, A.: Arosio. P. J. Biochem. 1992. 288, 591.

19. Levi, S.: Santambrogio. P: Cozzi. A.: Rovida E.: Corsi, B.: Tamborini. E.: Spada. S.: Albertini. A.: Arosio. P. J. M fol. Biol. 1994. 238.649 